\title{
Pregnancy with severe anemia: a dangerous combination with increase in maternal and perinatal morbidity and mortality. How can we prevent it?
}

\author{
Smita Tyagi $^{1 *}$, Natasha Tyagi ${ }^{2}$
}

\begin{abstract}
${ }^{1}$ Department of Obstetrics and Gynecology, Muzaffaranagar Medical College, Muzaffarnagar, Uttar Pradesh, India ${ }^{2}$ Department of Obstetrics and Gynecology, Guru Teg Bhadur Hospital and University College of Medical Sciences, Shahadra, Delhi, India
\end{abstract}

Received: 15 April 2017

Accepted: 30 May 2017

Accepted: 03 June 2017

\section{*Correspondence:}

Dr. Smita Tyagi,

E-mail: drsmitatyagi58@gmail.com

Copyright: (c) the author(s), publisher and licensee Medip Academy. This is an open-access article distributed under the terms of the Creative Commons Attribution Non-Commercial License, which permits unrestricted non-commercial use, distribution, and reproduction in any medium, provided the original work is properly cited.

\begin{abstract}
Background: Anaemia is a condition in which the number of red blood cells or their oxygen-carrying capacity is insufficient to meet physiologic needs, which vary by age, sex, altitude, smoking, and pregnancy status. In its severe form, it is associated with fatigue, weakness, dizziness and drowsiness. Pregnant women and children are particularly vulnerable.

Methods: This study was carried out in the Department of Obstetrics and Gynecology, Muzaffarnagar medical college, Muzaffarnagar and the data was taken according to the WHO.

Results: It was found that the prevalence of anemia was $91 \%$. According to WHO classification, out of this $44.9 \%$ were mildly anemic, $29.9 \%$ were moderately anemic and $25 \%$ were severely anemic.

Conclusions: The causes of anemia in pregnancy are illiteracy, poor socioeconomic status, improper distribution of iron and calcium tablets in rural areas due to poor health care intrastructure.
\end{abstract}

Keywords: Anemia, Calcium, Iron, Pregnancy

\section{INTRODUCTION}

Anemia is one of the most commonly encountered medical disorders during pregnancy.

According to $\mathrm{WHO}, \mathrm{Hb}$ level below $11 \mathrm{gm} \%$ in pregnant women constitutes anemia. ${ }^{1}$ Classification of Anemia according to $\mathrm{WHO}$ is as follows:

- $\quad$ Mild Anemia - 9-10.9 gm\%

- Moderate Anemia - 7-8.9 gm\%

- Severe Anemia - 4-6.9 gm\%
Pregnancy with Anemia is very common during pregnancy but when anemia is severe or very severe during pregnancy then there is drastic and dangerous increase in maternal and perinatal morbidity and mortality. ${ }^{2}$ According to United Nation declarations 1997, Anemia is a major public health problem that needs total elimination. The most common causes of maternal mortality according to WHO 2014 are PPH (15\%), complications from unsafe abortion $(15 \%)$, hypertensive disorders of pregnancy $(10 \%)$ post-partum infections $(8 \%)$ and obstructed labour $(6 \%){ }^{3}$ Indirect causes are malaria, anemia, HIV and Cardio vascular disease. 
Thus, anemia is high risk factor for direct cause (PPH, unsafe abortion, hyper tensive disorders, post-partum infections) and is important indirect cause of maternal mortality. More severe, the anemia, more risk of maternal mortality and morbidity and the most common cause of maternal death in developing countries like India is obstetrical Haemorrhage (directly related to anemia) followed by hyper tensive body disorder of pregnancy.

WHO 2014 also stated that at a country level, India (19\% $-56000)$ and Nigeria (14\% or 40000) accounted for roughly one third of the maternal deaths in $2010 .{ }^{3}$ United Nations population fund report-formely the UNFPAformerly the (United Nations fund for population activities) four elements are essential to maternal death prevention. First pre-natal care, second, skilled birth attendance with emergency backup. Third, emergency obstetric care to address major cause of maternal death which are haemorrhage, sepsis, unsafe abortion (all indirectly related to anemia) hyper tensive disorder and obstructed labour. Lastly post-natal care which is 6 wks following delivery. Prevention of anemia is very simple but still the prevalence of anemia is increasing especially in rural areas, so it is important to again evaluate the factors responsible for anemia and to prevent the. In this $21^{\text {st }}$ high tech century we can take the help of Smartphones and internet to prevent it.

\section{METHODS}

It is a prospective study done in the Department of Obstetrics \& Gynaecology for one year from September 2013 to August 2014. All the antenatal patients, and all the patients who were in labour and who had severe anemia according to WHO classification were taken $(\mathrm{Hb}$ $-6.9 \mathrm{gm} \%$ or below). Detailed history was taken to find out the cause of anemia. Other features which were noted were education, socio economic status, booked or unbooked and rural and urban areas. General examination and obstetric examination was done and along with routine investigations, all the investigations were sent to find out the cause, type and severity of anemia.

All the antenatal patients were given packed RBC transfusion, 2-3 in No., followed by parenteral iron if necessary depending on the gestational age. They were again counselled for regular antenatal check-up and delivery in hospital. All the patients who were in labour were again given 2-4 units of packed cell transfusion depending on the severity of anemia and patients were counselled about the complications of anemia. In this way, most of the patients of severe and very severe anemia were saved because of quick and aggressive transfusion of packed red cells.

\section{RESULTS}

Total No. of 14,400 pregnant patients attended our hospital in one year. Out of these 14,400 patients, 12,167 were antenatal patients and 2233 patients were in labour.
Table 1: Prevalence of anemia in pregnancy.

\begin{tabular}{|ll|}
\hline $\begin{array}{l}\text { Total no. of pregnant patients who } \\
\text { attended the hospital in one year }\end{array}$ & $\begin{array}{l}\text { Total no. of } \\
\text { patients }\end{array}$ \\
\hline $\begin{array}{l}\text { Total no. of antenatal patients in one } \\
\text { year }\end{array}$ & 14,400 \\
\hline $\begin{array}{l}\text { Total no. of patients who were in } \\
\text { labour in one year }\end{array}$ & 2,233 \\
\hline $\begin{array}{l}\text { Total no. of anemic patients } \\
\text { according to WHO classification }\end{array}$ & 13,104 \\
\hline$\%$ of anemic patients & $91 \%$ \\
\hline Mild anemia - 10.9 - 9 gm\% & $5896(44.9 \%)$ \\
\hline $\begin{array}{l}\text { Moderate anemia } \\
\text { Severe anemia }\end{array}$ & $3931(29.9 \%)$ \\
\hline
\end{tabular}

Out of these 14,400 patients, 13,104 patients were anemic according to WHO classification, that is $\mathrm{Hb}$ below 11 gm\%. This gives the prevalence of anemia of $91 \%$ in our study. Out of this $44.9 \%$ were mildly anemic, $29.9 \%$ were moderately anemic and $25 \%$ were severely anemia according to WHO classification. Prevalence of anemia of $91 \%$ is very high. It is a tertiary care centre near rural area and it was observed that all the patients (3277) of severe anemia were of rural area, all were unbooked cases with no antenatal care, all were illiterate with poor socioeconomic status. This shows the actual picture of social, economic, educational and health services of rural India, which are all co-related and needs a lot to be done in these areas.

Table 2: Age distribution of patients of pregnancy with severe anemia.

\begin{tabular}{|l|l|l|}
\hline Age Group & Total no. of patients & $\%$ \\
\hline 20-25 Years & 1375 & 41.9 \\
\hline 26-30 Years & 786 & 24.0 \\
\hline 31-35 Years & 983 & 30.0 \\
\hline 36-40 Years & 133 & 04.0 \\
\hline Total & 3277 & \\
\hline
\end{tabular}

Maximum no. of patients $(41.9 \%)$ were of young age group of 20-25 years indicating these girls were malnourished in their childhood and adolescence. Thus, it also co-relates severe anemia with illiteracy and poor socioeconomic status of rural India.

Table 3: Gestational age of the patients of severe anemia.

\begin{tabular}{|lll|}
\hline Gestational age & No. of patients & $\%$ \\
\hline up to 12 weeks & 196 & 05.90 \\
\hline $13-26$ weeks & 458 & 13.90 \\
\hline $27-40$ weeks & 2623 & 80.04 \\
\hline Total & 3277 & \\
\hline
\end{tabular}

Maximum no. of patients $(80.04 \%)$ were of third trimester, indicating the urgent need of treatment of 
severe anemia in these patients. It also indicates that women are reluctant to attend the antenatal OPD during first trimester due to ignorance, illiteracy and social reasons and came to our hospital during third trimester when anemia become severe and complications of anemia compel them to see a doctor.

Table 4: Gravidity of the patients of severe anemia.

\begin{tabular}{|lll|}
\hline Gravida & No. of patients & $\%$ \\
\hline $1^{\text {st }}$ and $2^{\text {nd }}$ Gravida & 1376 & 41.90 \\
\hline $3^{\text {rd }}$ and $4^{\text {th }}$ Gravida & 1179 & 35.90 \\
\hline $5^{\text {th }}$ Gravida and above & 722 & 22.03 \\
\hline Total & 3277 & \\
\hline
\end{tabular}

Maximum No. of patients $(41.9 \%)$ were $1^{\text {st }}$ and $2^{\text {nd }}$ Gravida in severe anemia. It also indicates that these patients were anemic even in their non-pregnant states.

Table 5: Antenatal complications in severe anemia.

\begin{tabular}{|lll|}
\hline Complications & No. of patients & $\%$ \\
\hline IUGR & 494 & 26 \\
\hline PIH & 285 & 15 \\
\hline Fever & 285 & 15 \\
\hline CHF & 57 & 3 \\
\hline Total & 1900 & \\
\hline
\end{tabular}

Out of 3277 patients of severe anemia, 1900 (58\%) were antenatal patients. They were all unbooked cases of rural areas and come for antenatal visit because they were feeling weakness and were unable to do their routine house hold work, so they persued their husbands or inlaws for antenatal checkup and we were surprised to see severe anemia in these patients. 494 patients $(26 \%)$ of severe anemia had IUGR, 285 (15\%) had PIH, $285(15 \%)$ had fever and $57(3 \%)$ patients had CHF. All these patients were treated with packed red cell transfusion and parentral iron according to the period of gestation and all were counselled for regular antenatal checkup, but to our surprise most of the patients (approximately 98\%) did not turned up for regular antenatal checkup or delivery. So, all these complications of severe anemia are only tip of iceberg and needs further evaluation, because most of these patients were poor and ignorant (inspite of counselling) and were delivered at home.

Table 6: Intrapartum complications of severe anemia total 1377 patients.

\begin{tabular}{|lll|}
\hline Complications & No. of patients & $\%$ \\
\hline Preterm Delivery & 667 & 48.4 \\
\hline CHF & 55 & 3.9 \\
\hline
\end{tabular}

Out of 3277 patients of severe anemia, 1377 patients were in labour. Patients of severe anemia in labour is a very dangerous combination because we have very little time to treat them. These patients were given very quick and aggressive treatment with packed RBC transfusion and we tried our best to save them.
Table 7: Post partum complications in severe anemia (total patients-1377).

\begin{tabular}{|lll|}
\hline Complications & No. of patients & $\%$ \\
\hline PPH & 261 & 19.9 \\
\hline Sepsis & 206 & 15.0 \\
\hline Subinvolution & 110 & 08.0 \\
\hline CHF & 27 & 02.0 \\
\hline
\end{tabular}

261 (19.9\%) patients had PPH, 206 (15\%) had sepsis, 110 $(08.0 \%)$ patients had subinvolution of uterus and 27(02.0\%) patients went into CHF.

Table 8: Maternal mortality in pregnancy with severe anemia (Total 1377 patients).

\begin{tabular}{|lll|}
\hline $\begin{array}{l}\text { Cause of maternal } \\
\text { mortality }\end{array}$ & No. of patients & $\%$ \\
\hline CHF & 32 & 58 \\
\hline PPH & 23 & 42 \\
\hline Total & 55 & 4 \\
\hline
\end{tabular}

Maternal mortality is $4 \%$ in patients of severe anemia in labour. 58\% patients died due to PPH. Most of the patients of severe anemia in labour were saved by quick and aggressive treatment of blood transfusion, but this is only tip of iceberg because $98 \%$ of the antenatal patients of severe anemia did not turned again and were delivered elsewhere, mostly home delivery.

Table 9: Perinatal complications in severe anemia (Total patients - 1377).

\begin{tabular}{|lll|}
\hline Complications & No. of patients & $\%$ \\
\hline low birth weight & 667 & 48.4 \\
\hline IUGR & 481 & 35.0 \\
\hline IUD & 82 & 05.0 \\
\hline
\end{tabular}

In present study, low birth weight was 667 (48.4\%), IUGR $481(35.0 \%)$ and IUD was $82(05.0 \%)$.

\section{DISCUSSION}

In present study, Prevalence of anemia is very high $(91 \%)$. It is also very high in study done by Gupta $\mathrm{N}$ et al and J.B. Sharma et al. ${ }^{4,5}$ This shows that prevalence is still very high in developing countries and is not decreasing even after lots of measures done by govt. in this field. According to WHO global database, worldwide prevalence of anemia, global prevalence of anemia in pregnancy is $41.8 \%$, out of which $55.8 \%$ is in Africa which highest and $6.1 \%$ is in North America which is lowest. ${ }^{6}$ Asia has $41.6 \%$ prevalence of anemia which is $2^{\text {nd }}$ highest. The incidence is very high $(91 \%)$ in present study, because it is from rural India. Prevalence of severe anemia is $25 \%$ in present study. It is $10 \%$ in study done by Gupta $\mathrm{N}$ et al, and $2.1 \%$ in study done by Bukaretal., ${ }^{4}$ It was observed maximum no. patients $(41.9 \%)$ were of young age group of 20-25 years, maximum no. of 
patients $(80.04 \%)$ were of third trimester, and maximum no. of patients $(41.9 \%)$ were $1^{\text {st }}$ and $2^{\text {nd }}$ Gravida with severe anemia. Bukar et al in Nigeria also noted that mean age was 24 years and $97 \%$ of patients were $2^{\text {nd }}$ and $3^{\text {rd }}$ gravida. $^{7}$ This is in accordance with our study as both are developing countries. Most common Antenatal complication was IUGR (26\%) followed by PIH (15\%), fever $(15 \%)$, and CHF (3\%). Most common intrapartum complication was preterm delivery $(48.4 \%)$ and $\mathrm{CHF}$ (3.9\%) and most common post partum complication was PPH $(19.9 \%)$. Gupta $\mathrm{N}$ et al also noted preeclampsia to be $45.4 \%$, infection to be $96 \%$ and $\mathrm{CHF}$ to be $6 \%$ in pregnancy with severe anemia. ${ }^{4}$ Study was further supported by LOPS, VR et al. ${ }^{8}$ Gupta $\mathrm{N}$ et al also noted preterm labour to be $42 \%$ and CHF to be $3.9 \%$ and PPH to be $43.6 \% .^{4}$ This is in accordance with present study. Maternal mortality was $4 \%$ and intrauterine death was $5.0 \%$ in our study. Fernando Viteri in, Umberjali Bakhtier $\mathrm{U}$ et al and Lone FW et al also reported that risk of death increases with severe anemia in Pregnancy. ${ }^{9-11} \mathrm{In}$ present study, low birth weight was $48.4 \%$, IUGR $35.0 \%$ and IUD was $05.0 \%$. This study was further supported by Gupta $\mathrm{N}$ et al, who found low birth weight to be $43 \%$, IUGR $35 \%$ and IUD to be $44 \%$ in severe anemia. ${ }^{4}$

\section{CONCLUSION}

Pregnancy with severe anemia is curse for pregnant women. It causes maximum harm to both mother and fetus. It is specially dangerous during labour when we have very little time to treat it. In our study the causes are illiteracy, ignorance, poor socioeconomic status, improper distribution of iron and calcium tablets in rural areas due to poor health care intrastructure and last but not the least is lack of quick transport facilities to tertiary care centre Measures to treat anemia should be taken right from the childhood. Govt. has already launched various programmers like mid-day meals, specially fortified with Iron and Calcium to Children and distribution of Iron and Calcium tablets to pregnant women during Anteratal period and Janane Suraksha Yojna during labour, still the incidence of anemia in pregnancy has not come down. Thus, there is need to implement new programmes to prevent and treat anemia during pregnancy.

Two major programmes which can be implemented are mobile vans equipped with doctors and para medical staff, small lab for blood examination and medicines for pregnant women. Thus, we have to reach the pregnant women at their homes. Last but not the least is the improvement of quick transport facilities of the patient to tertiary care centre. U.P Govt. National Ambulance services has been very successful to achieve it. In this 21 st century, we can also use smart phones and internet services. The can be provided to both patients and doctors and it will help very efficiently to decrease maternal and perinatal morbidity and mortality.

Funding: No funding sources

Conflict of interest: None declared

Ethical approval: The study was approved by the Institutional Ethics Committee

\section{REFERENCES}

1. WHO-The prevalence of anemia in women. A tabulation of available information; second edition. Geneva: WHO; 1992. (WHO/MCH/MSM/92.2).

2. Sharma JB, Shankar M. Anemia in Pregnancy. JIMSA. 2010;23(4):253-60.

3. WHO. Trends in maternal mortality: 1990-2013. 2014. Available http://apps.who.int/iris/bitstream/10665/112682/2/97 89241507226_eng.pdf?ua=1. Retrieved 2 Aug 2016.

4. Gupta N, Trivedi S, Singh N, Anand, S, Usmani F. High prevalence of anemia in pregnancy still a major health problem in India. Journal of U.P. Chapter of Obstet Gynecol. 2015;23(1):47-52.

5. Sharma JB. Nutritional anemia during pregnancy in non industrial countires, progress. Obstet Gynecol. 2003;15:103-122.

6. de Benoist B, McLean E, Egli I, Cogswell M. WHO Global Database on anemia - world wide prevalence of anemia 1993-2005. Available at http://apps.who.int/iris/bitstream/10665/43894/1/978 9241596657_eng.pdf

7. Bukar M, Audu BM, Sadauki HM, Elnafaty AU, Mairiga AG. Prevalence of iron deficiency and megaloblastic anaemia at booking in a secondary health facility in north eastern Nigeria. Nigerian Med J. 2009;50(2):33.

8. Lops VR, Hunder LP, Dixon LR. Anemia in pregnancy. Am Fam Physician. 1995;51(5):1189-97.

9. Viteri FE. The consequences of iron deficiency and anemia in pregnancy. In: Nutrient Regulation during pregnancy, Lactation and infant growth. L. Alien, J. Kng and B. Onnerdal. Eds. Plenum press, New York;1994:121-133.

10. Umber JB, Yasmeen K, Rasia N, Relationship between maternal haemoglobin and perinatal outcome. Rawal Medicine J. 2007;32:102-4.

11. Lone FW, Qureshi RN, Emmanuel F. Maternal anemia and its impact on perinatal outcome in a tertiary care hospital in Pakistan. Eastern Mediterrranean Health J. 2004;10(6):801-7.

Cite this article as: Tyagi $\mathrm{S}$, Tyagi N. Pregnancy with severe anemia: a dangerous combination with increase in maternal and perinatal morbidity and mortality. How can we prevent it?. Int J Reprod Contracept Obstet Gynecol 2017;6:3151-4. 